\title{
Polynucleotide Sequence Divergence in the Genus Citrobacter
}

\author{
By J. H. CROSA*, A. G. STEIGERWALT, G. R. FANNING \\ AND D. J. BRENNER \\ Division of Biochemistry, Walter Reed Army Institute of Research, \\ Washington, D.C. 20012 , U.S.A.
}

(Received 22 November 1973; revised I February 1974)

\begin{abstract}
SU M MAR Y
Deoxyribonucleic acid reassociation was used to assess divergence in species of Citrobacter and Citrobacter-like strains. Typical strains of Citrobacter freundii were highly related. Antigenically atypical strains and most biochemically atypical strains showed a lower, but species level, of relatedness to typical $C$. freundii. Four additional relatedness groups were detected. One of these corresponded to $C$. diversus, including Levinea malonatica. A second contained L. amalonatica. A third group contained two indole ${ }^{+}$strains which exhibited only 40 to $50 \%$ relatedness to other groups of Citrobacter. The fourth group contained $\mathrm{H}_{2} \mathrm{~S}^{-}$, lysine ${ }^{+}$organisms that are more closely related to Serratia than to Citrobacter.
\end{abstract}

\section{INTRODUCTION}

In a study on polynucleotide sequence relationships in the tribe Salmonelleae, our findings indicated that bacteria included in the genus Citrobacter have substantially diverged from other members of the tribe (Crosa, Brenner, Ewing \& Falkow, 1973).

The genus Citrobacter is composed of strains that are, in general, biochemically similar. Until the past few years all strains, including slow lactose-fermenting Bethesda strains and various biotypes, were designated as $C$. freundii. Recently, several laboratories have described additional species of Citrobacter or proposed new genera for groups of bacteria previously considered as $C$. freundii.

Macierewicz (1966) proposed the genus Padlewskia for hydrogen sulphide negative, adonitol positive strains. Fredriksen (1970) described a similar set of strains and proposed the name $C$. koseri. Young, Kenton, Hobbs \& Moody (1971) proposed a new genus, Levinea, with two species, L. malonatica and $L$. amalonatica. These strains also ferment adonitol and are hydrogen sulphide negative and indole positive. The two species differ in their ability to utilize malonate. Ewing and Davis (Davis \& Ewing, 1966, 1971; Ewing \& Davis, 1972) described a large number of strains that ferment adonitol, and are hydrogen sulphide and potassium cyanide negative and indole positive, naming them Citrobacter diversus (Davis \& Ewing, 1971; Ewing \& Davis, 1972). These authors think that Padlewskia and $C$. koseri are similar to $C$. diversus, and that Levinea species are $\mathrm{KCN}$ positive variants of $C$. diversus.

Another group of atypical 'Citrobacter-like' strains was reported by Leclerc \& Buttiaux (1965). These bacteria were hydrogen sulphide negative and decarboxylated lysine. Data from Edwards \& Ewing (1972), Ewing \& Davis (1972) and Young et al. (1971) indicate that neither Citrobacter nor Levinea can decarboxylate lysine.

* Present address: Department of Microbiology, University of Washington, Seattle, Washington 98195 U.S.A. 
In this paper we discuss results obtained from interspecific DNA reassociation tests on representatives of typical and atypical $C$. freundii, $C$. diversus, and Levinea species.

\section{METHODS}

Bacteria and media. The strains used (unless designated below) were obtained from W. H. Ewing and G. Hermann and had been characterized biochemically and antigenically at the Center for Disease Control, Atlanta, Georgia, U.S.A. Enterobacter agglomerans, Erwinia dissolvens and E. amylovora strains were from M. P. Starr (International Collection of Phytopathogenic Bacteria), and Pectobacterium carotovorum from the American Type Culture Collection. Citrobacter strains IC, I84-6, H3IO, 5 I7-60, P I IC, Zurich and 3796 were obtained from S. Schaefler, Enterobacter cloacae I 65 from V. J. Brenner, strains of Levinea species including type strains 25408 (L. malonatica) and 25406 (L. amalonatica) from V. M. Young, and Proteus mirabilis I from S. Falkow. Salmonella typhimurium LT2 and Shigella flexneri 24570 have been described previously (Brenner et al. 1969a). Bacteria were maintained on meat extract agar slants and cultivated on brain heart infusion broth (Difco) at $37^{\circ} \mathrm{C}$. The medium employed for labelling the cells was as described by Crosa et al. (1973).

Preparation of DNA and DNA reassociation. Both unlabelled and ${ }^{32}$ P-labelled DNA were prepared, purified and sheared as described previously (Crosa et al. 1973). DNA reassociation reactions were carried out to a Cot (concentration $\times$ time, parameters of DNA reassociation, Britten \& Kohne, I966) of about 100 for the unlabelled DNA in mixtures containing $0 . \mathrm{I} \mu \mathrm{g}$ of sheared, denatured ${ }^{32} \mathrm{P}$-labelled $\mathrm{DNA} / \mathrm{ml}$ from the reference strain and a 1500 -fold excess of sheared, denatured, unlabelled bacterial DNA, in $0.28 \mathrm{M}$-phosphate buffer (PB: $0.14 \mathrm{M}-\mathrm{Na}_{2} \mathrm{HPO}_{4}+0.14 \mathrm{M}-\mathrm{NaH}_{2} \mathrm{PO}_{4}, \mathrm{pH}$ 6.8). Incubations were carried out at either 60 or $75^{\circ} \mathrm{C}$. Estimation of DNA reassociated in the above conditions was made by the use of hydroxyapatite (HA) for the separation of single-stranded DNA from reassociated DNA in $0.14 \mathrm{M}-\mathrm{PB}+$ sodium dodecyl sulphate, by means of a batch procedure (Brenner, Fanning, Rake \& Johnson, I $969 b$ ). The thermal stability of reassociated DNA was assessed by a stepwise elution at increasing temperatures, as described by Crosa et al. (1973).

In control experiments the reassociation of labelled DNA was $2.5 \%$ or less.

Spectrophotometric determination of genome size. The molecular complexity of bacterial DNA was determined as previously described (Crosa et al. 1973).

\section{RESULTS}

DNA relatedness among citrobacteria was first assessed using labelled reference DNA from a typical $C$. freundii strain, 460-6I (Table I). Typical strains of $C$. freundii are hydrogen sulphide positive, indole negative, potassium cyanide positive, and malonate negative. These reactions will henceforth be referred to by a + or - sign (e.g. +-+- indicates $\mathrm{H}_{2} \mathrm{~S}$ positive, indole negative, $\mathrm{KCN}$ positive, malonate negative). DNA reassociation reactions were carried out at $60{ }^{\circ} \mathrm{C}$ and, in many cases, at $75^{\circ} \mathrm{C}$. The stability of a given DNA duplex is assessed by determining its $T_{m(e)}$, i.e. that temperature at which $50 \%$ of reassociated DNA is eluted from $\mathrm{HA}$.

We assumed that each $1 \%$ of unpaired bases in reassociated DNA causes a $\mathrm{I}^{\circ}$ decrease in $T_{m(e)}$ (Laird, McConaughy \& McCarthy, 1969). Therefore the $\Delta T_{m(e)}\left(T_{m(e)}\right.$ homoduplex $-T_{m(e)}$ heteroduplex) can be used as an index of base sequence divergence in related DNA.

In $60^{\circ} \mathrm{C}$ reactions, four typical strains of $C$. freundii and seven typical or malonate positive 
Table I. Relative relatedness of enterobacteria to the typical C. freundii strain 460-6I

$60 \mathrm{C}$

Source of unlabelled DNA

C. fieundii 460-6I +- +-

C. freundii 3062-62 +- +-

C. freundii $4675-65+-+-$

C. freundii 5245-60 +- +-

Bethesda IA +-++

Bethesda $2 \mathrm{~A}+-++$

Bethesda 3A + - + -

Bethesda $4 \mathrm{~A}+-++$

Bethesda $7+-+-$

Bethesda $8 \mathrm{~A}+-++$

Bethesda 9A +-+-

C. freundii IC:

C. freundii $\mathrm{H} 3 \mathrm{IO} \neq$

C. freundii PI IC

C. freundii $184-6$ :

C. freundii 3796 :

C. freundii Zurich:

C. fremindii $5118-60--+-$

C. freundii 2987-57 - - + -

C. freundii 6440-59--++

C. freundii $876-58 \cdots-+$

Bethesda $6+-++$

Bethesda 29A +-++

C. diversus 1066-70 - +-+

C. diversus $1381-70-+-+$

C. diversus 2292-70 - +- +

C. diversus $36 \mathrm{I} 3-63-+\cdots+$

L. malonatica $25408-+++$

L. malonatica $25409-+++$

L. malonatica $254 \mathrm{IO}-+++$

L. amalonatica $25406-++-$

L. amalonatica $25407-++-$

S. typhimurium LT2

S. marinus III 2

S. chameleon I I I0

Arizona 1

Arizona 62

Arizona III

Arizona 118

E. coli $\mathrm{KI} 2$

E. coli $\mathrm{в}$

S. flexneri 24570

E. aerogenes 1627-66

E. cloacae 165

E. cloacae 1347-71

E. dissolvens EDII4

$K$. pneumoniae 2

E. agglomerans 2553

E. hafiniae

S. marcescens SM6-W2

Edwardsiella tarda $1126-64$

Erwinia amylovora EAI69

Pectobacterium carotovorum 495

Proteus mirabilis I

\begin{tabular}{|c|c|}
\hline $\begin{array}{c}\text { Binding } \\
(\%)\end{array}$ & $\Delta T_{m(e)}{ }^{*}$ \\
\hline 100 & - \\
\hline 96 & 0.7 \\
\hline 96 & 0.9 \\
\hline 92 & 0.5 \\
\hline 90 & 3.6 \\
\hline 95 & 0.4 \\
\hline 97 & 0.9 \\
\hline 94 & 0.9 \\
\hline 94 & 0.8 \\
\hline 95 & $3 \cdot 3$ \\
\hline 97 & 0.7 \\
\hline 83 & 5.8 \\
\hline 76 & $9 \cdot 4$ \\
\hline 82 & 6.5 \\
\hline 82 & 70 \\
\hline $8 \mathrm{I}$ & 6.5 \\
\hline 83 & 6.4 \\
\hline 97 & 0.8 \\
\hline 85 & $4 \cdot 8$ \\
\hline 93 & 0.9 \\
\hline 80 & $7 \cdot 7$ \\
\hline 86 & $6 \cdot 5$ \\
\hline 87 & 6.5 \\
\hline 70 & II 4 \\
\hline 65 & 11.8 \\
\hline 68 & $9 \cdot 7$ \\
\hline 68 & II'9 \\
\hline 64 & 12.0 \\
\hline 68 & II 8 \\
\hline 63 & II 6 \\
\hline 66 & 12.3 \\
\hline 62 & 12.8 \\
\hline 60 & 13.5 \\
\hline 60 & 13.7 \\
\hline 61 & 13.7 \\
\hline $5^{8}$ & 12.5 \\
\hline 55 & 14.0 \\
\hline 61 & 12.8 \\
\hline 56 & 12.6 \\
\hline 59 & 143 \\
\hline 59 & - \\
\hline 57 & - \\
\hline 47 & $14 \cdot 3$ \\
\hline 44 & $\begin{array}{l}16.0 \\
\end{array}$ \\
\hline 55 & 14.0 \\
\hline 44 & 146 \\
\hline 52 & 139 \\
\hline 30 & 17.8 \\
\hline 20 & 16.6 \\
\hline 34 & 15.5 \\
\hline 25 & 17.5 \\
\hline 28 & 18.4 \\
\hline 30 & 17.2 \\
\hline II & $20 \cdot I$ \\
\hline
\end{tabular}

$75 \mathrm{C}$

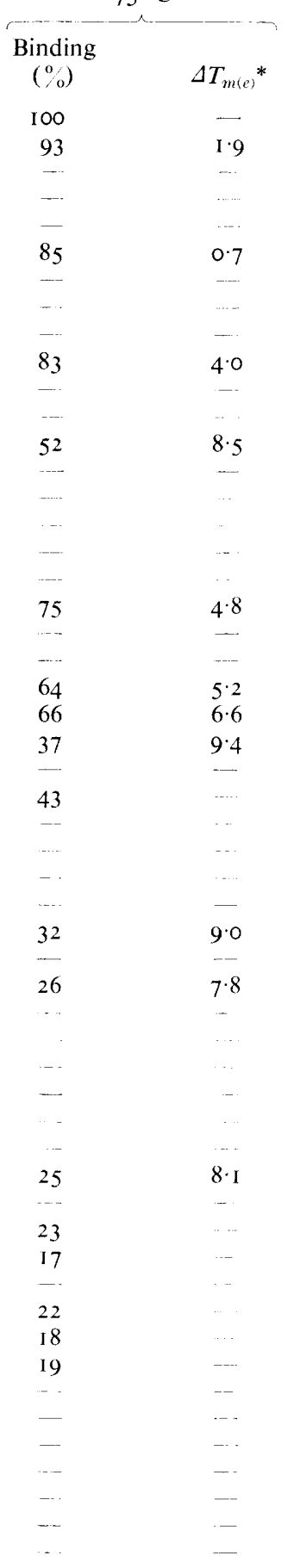

* $T_{m(e)}$, thermal elution midpoint; that temperature at which $50 \%$ of the DNA bound to HA at the 60 or $75 \mathrm{C}$ incubation temperature is eluted. $\Delta T_{m(e)}$ is the decrease in $T_{m(e)}$ between heterologous DNA reactions and the homologous $C$. freundii reaction.

$\dagger$ The plus and minus symbols represent positive or negative reactions for $\mathrm{H}_{2} \mathrm{~S}$, indole, $\mathrm{KCN}$ and malonate, respectively (see text).

$¥$ These strains have atypical antigens. 
Table 2. Relative relatedness of Citrobacter strains to the atypical C. freundii strain $876-58$

\begin{tabular}{|c|c|c|}
\hline Source of unlabelled DNA $\dagger$ & $\begin{array}{l}\text { Binding at } \\
60 \mathrm{C}(\%)\end{array}$ & $\begin{array}{c}\Delta T_{m(e)}{ }^{*} \text { at } \\
60{ }^{\circ} \mathrm{C}\end{array}$ \\
\hline C. freundii $876-58--++$ & 100 & - \\
\hline C. freundii $6440-59 \cdots++$ & 70 & $7 \cdot 0$ \\
\hline C. freundii $2987-57--+\cdot-$ & 68 & $8 \cdot 2$ \\
\hline C. freundii $5 \mathrm{I} 18-60--+-$ & 75 & $7 \cdot 1$ \\
\hline Bethesda $6+-++$ & 77 & $6 \cdot 2$ \\
\hline Bethesda $29 \mathrm{~A}+-++$ & 74 & $6 \cdot 2$ \\
\hline C. freundii $5245-60$ & 72 & $7 \cdot 1$ \\
\hline C. freundii $460-61+-+-$ & 69 & $7 \cdot 0$ \\
\hline C. freundii $3062-62+-+\cdots$ & 77 & $7 \cdot 2$ \\
\hline C. freundii $4675-65+-+--$ & 73 & $7 \cdot 1$ \\
\hline Bethesda $3 \mathrm{~A}+-+-$ & 71 & $6 \cdot 6$ \\
\hline 'Citrobacter-like' $4552-71--++$ lys & 34 & $18 \cdot 5$ \\
\hline 'Citrobacter-like' $4553-7$ I --++ lys & $3 \mathrm{I}$ & 17.6 \\
\hline 'Citrobacter-like' 4554-7I --++ lys $^{+}$ & 31 & I 6.6 \\
\hline 'Citrobacter-like' $4556-71--++$ lys $^{+}$ & 34 & $17 \cdot 8$ \\
\hline 'Citrobacter-like' 4557-7I --++ lys' & 34 & $18 \cdot 0$ \\
\hline C. diversus $1066-70-+-+$ & 59 & $10 \cdot 4$ \\
\hline C. diversus $138 \mathrm{I}-70-+-+$ & 60 & $10 \cdot 1$ \\
\hline C. diversus $2292-70-+-+$ & 60 & $10 \cdot I$ \\
\hline C. diversus $3613-63-+-+$ & $6 \mathrm{I}$ & $9 \cdot 8$ \\
\hline L. malonatica $25408-+++$ & 58 & $9 \cdot 9$ \\
\hline L. malonatica $25409-+++$ & 59 & $9 \cdot 9$ \\
\hline L. malonatica $25410-+++$ & 55 & $9 \cdot 8$ \\
\hline L. amalonatica $25405-++-$ & 57 & $11 \cdot 3$ \\
\hline L. amalonatica $25407-++-$ & 56 & $11 \cdot 4$ \\
\hline
\end{tabular}

Bethesda strains exhibited an average of $95 \%$ relatedness to $C$. freundii $460-6 \mathrm{I}$. The related sequences exhibited only 0.5 to $3.6 \%$ unpaired bases. At $75{ }^{\circ} \mathrm{C}$, relatedness and thermal stability of related sequences remained high. Two other Bethesda strains $(+-++)$ exhibited somewhat lower relatedness and duplex stability in reactions with $C$. freundii 460-6I.

Citrobacter freundii which are atypical in that they possess Salmonella or Escherichia coli antigens showed some $80 \%$ relatedness to $C$. freundii $460-6 \mathrm{I}$. In this case 6 to $9 \%$ divergence is present in related sequences. Biochemically atypical $C$. freundii appeared to show two patterns of relatedness to $460-6 \mathrm{I}$. Two strains show some $95 \%$ relatedness and less than I \% divergence; five other strains exhibit 80 to $87 \%$ relatedness with 5 to $8 \%$ divergence. A 10 to $20 \%$ reduction in relatedness occurs in reactions carried out at $75{ }^{\circ} \mathrm{C}$. There is no observable correlation between the pattern of relatedness and the biochemical reactions in --+- and $-\cdots++$ strains.

Citrobacter diversus, Levinea malonatica and L. amalonatica strains are 60 to $70 \%$ related to $C$. freundii 460-61. Extensive ( 10 to $13 \%$ ) divergence is present in these heteroduplexes. Approximately half of these related sequences are sufficiently related to remain stable in $75^{\circ} \mathrm{C}$ incubations.

C. freundii 460-6I is 45 to $60 \%$ related to Salmonella, Arizona, Shigella, E. coli, Klebsiella, Enterobacter cloacae, E. aerogenes and Erwinia dissolvens. Divergence in these reactions is 12 to $16 \%$. Relatedness falls by $2 \cdot 5$ - to 3 -fold when these reactions are carried out at $75{ }^{\circ} \mathrm{C}$. Relatedness between $C$. freundii 460-6I and representatives of Enterobacter agglomerans, E. hafniae, Serratia marcescens, Erwinia amylovora, Pectobacterium carotovorum and 
Table 3. Relative relatedness of Citrobacter strains to $\mathrm{H}_{2} \mathrm{~S}^{+}$, indole ${ }^{+}, \mathrm{KCN}^{+}$, malonate ${ }^{-}$strains of $C$. freundii

\section{C. freundii $3158-63$}

Binding

Source of unlabelled DNA

C. freundii 3158-63 +++-

C. freundii $80-58+++-$

C. freundii $1636-6 \mathrm{I}+++-$

C. freundii $\mathrm{1} 637-6 \mathrm{I}+++-$

C. freundii 3104-6I +++-

C. freundii $2970-59+++-$

C. freundii $2990-58+++-$

C. freundii $892-6 \mathrm{I}+++-$

Bethesda $6+-++$

Bethesda 29A +-++

C. freundii $876-58--++$

C. freundii $6440-59-\cdots++$

C. freundii $2987-57--+-$

C. freundii 5I I 8-60 - - +

C. diversus $1381-70-+-+$

C. diversus 3613-63 -+-+

L. malonatica $25409-+++$

L. amalonatica $25406-++-$

L. amalonatica $25407-++-$

C. freundii $460-6 \mathrm{I}+-+-$

C. freundii 3062-62 +-+-

C. freundii 4675-65 + - + -

C. freundii 5245-60 + + +

Bethesda $1 \mathrm{~A}+-++$

Bethesda $4 \mathrm{~A}+-++$

C. freundii Zurich $\ddagger$

C. freundii PII-C

$$
2 \cdot 7
$$

\section{C. freundii $80-58$}

Binding

$(\%)$ at $60 \mathrm{C}$

100

87

55

56

78

73

89

86

85

82

76

67

84

62

-.

-

$-$

78

80

77

69

70

68

83$$
\text { - }
$$$$
\text { I } 2 \cdot 8
$$$$
11 \cdot 9
$$

8.0

$7 \cdot 8$

0.0

$$
\text { 3. I }
$$

$3 \cdot 2$

$8 \cdot 2$

$7 \cdot 5$

8.9

8. I

I I 6

$-$

$-$

-

$7 \cdot 3$

$\begin{array}{r}7 \cdot 8 \\ \hline\end{array}$

9.0

$7 \cdot 2$

$7 \cdot 6$

$7 \cdot 5$

6.0 $\begin{array}{cr}6 \% & \Delta T_{m(e)}{ }^{*} \\ & \text { at } 60 \mathrm{C}\end{array}$

$\begin{array}{ll}71 & 2 \cdot 2\end{array}$

71
$100 \quad 2 \cdot 2$
46

$\begin{array}{ll}46 & \cdots \\ 4 \mathrm{I} & -\end{array}$

$64 \quad 7 \cdot 2$

$54 \quad 8 \cdot 8$

$73 \quad 2.5$

$70 \quad 5.1$

$77 \quad 1.7$

$76 \quad \mathrm{I} \cdot 3$

$69 \quad 6.0$

62

58

58
69

50

50

5 I

49

52

65

67

66

65

60

$6 \mathrm{I}$

70

$8 \mathrm{I}$
C. freundii $1636-6 \mathrm{I}$

Binding

$(\%)$ at $60{ }^{\circ} \mathrm{C}$

\begin{tabular}{rc}
43 & - \\
48 & $13 \cdot 6$ \\
100 & - \\
98 & $0 \cdot 0$ \\
76 & $3 \cdot 0$ \\
48 & - \\
48 & - \\
- & - \\
48 & - \\
51 & - \\
$5 \mathrm{I}$ & - \\
52 & - \\
46 & - \\
50 & - \\
53 & - \\
- & - \\
- & - \\
- & - \\
\hline 49 & - \\
$5 \mathrm{I}$ & - \\
44 & - \\
52 & - \\
47 & $13 \cdot 7$ \\
50 & - \\
50 & - \\
- & -
\end{tabular}

* See Table I for a definition of $\Delta T_{m(e)}$.

$\uparrow$ See Table I for plus and minus code.

$\$$ These strains have atypical antigens.

Edwardsiella tarda are 20 to $35 \%$, with I 5 to $18 \%$ divergence in related sequences. Minimal relatedness is present between $C$. freundii $460-6$ I and Proteus mirabilis.

Relatedness among atypical $C$. freundii was tested with reference DNA from the --++ strain $C$. freundii 876-58 (Table 2). Both atypical and typical $C$. freundii exhibited some 70 to $75 \%$ relatedness with $C$. freundii $876-58$ in $60{ }^{\circ} \mathrm{C}$ reassociation reactions. Related sequences exhibited 6 to $8 \%$ divergence. Based on their reactions with $C$. freundii $460-6 \mathrm{I}$ (Table I), it was expected that the two --++ strains, 876-58 and 6440-59, should be about $70 \%$ related. Reciprocal reassociation reactions between strains $460-6 \mathrm{I}$ and $876-58$ show similar thermal stability, but different levels of relatedness; $69 \%$ of strain $876-58$ DNA is related to $80 \%$ of strain $460-6$ I DNA. Therefore, the genome of strain $876-58$ is some $16 \%$ larger than that of strain $460-6 \mathrm{I}$.

A group of $\mathrm{H}_{2} \mathrm{~S}^{-}$, lysine positive strains described as perhaps ' Citrobacter-like' by Leclerc \& Buttiaux (I965) exhibited only 3 I to $34 \%$ relatedness (I $6 \cdot 5$ to $18.5 \%$ divergence) to C. freundii 876-58.

Heterogeneity in atypical $C$. freundii was also assessed using reference DNAs from three +++- strains (I636-6I, 3158-63 and 80-58). These data, shown in Table 3, indicate extensive divergence among +++- strains, as well as substantial differences in genome 
Table 4. Relatedness of Citrobacter strains to Levinea species

\begin{tabular}{|c|c|c|c|c|c|c|c|c|}
\hline \multirow[b]{2}{*}{ Source of unlabelled DNA† } & \multicolumn{4}{|c|}{ L. malonatica 25408} & \multicolumn{4}{|c|}{ L. amalonatica 25406} \\
\hline & $\begin{array}{c}\text { Binding } \\
\text { at } 60 \mathrm{C} \\
(\%)\end{array}$ & $\begin{array}{c}\Delta T_{m(e)^{*}} \\
\text { at } 60^{\circ} \mathrm{C}\end{array}$ & $\begin{array}{c}\text { Binding } \\
\text { at } 75 \% \mathrm{C} \\
(\%)\end{array}$ & $\begin{array}{l}\Delta T_{m(e)}{ }^{*} \\
\text { at } 75 \mathrm{C}\end{array}$ & $\begin{array}{c}\text { Binding } \\
\text { at } 60 \mathrm{C} \\
(\%)\end{array}$ & $\begin{array}{l}\Delta T_{m(e)}{ }^{*} \\
\text { at } 60 \mathrm{C}\end{array}$ & $\begin{array}{c}\text { Binding } \\
\text { at } 75 \mathrm{C} \\
(0)\end{array}$ & $\begin{array}{l}\Delta T_{m(t)} \\
\text { at } 75\end{array}$ \\
\hline L. amalonatica $25405-+++$ & 56 & $11 \cdot 9$ & 35 & $8 \cdot 0$ & 100 & 0.1 & 100 & 0.1 \\
\hline L. amalonatica $25406-+++$ & 56 & $11 \cdot 9$ & 34 & $8 \cdot 7$ & 100 & - & 100 & - \\
\hline L. amalonatica $25407-+++$ & 66 & $11 \cdot 3$ & 42 & $6 \cdot 7$ & 94 & 0.1 & 93 & 0.0 \\
\hline L. malonatica $25408-++-$ & 100 & - & 100 & $\cdots$ & 63 & $1 \cdot 3$ & 37 & $7 \cdot 3$ \\
\hline L. malonatica $25409-++-$ & 88 & 0.9 & 86 & 0.7 & 58 & $12 \cdot I$ & 33 & $7 \cdot 8$ \\
\hline L. malonatica $254 \mathrm{IO}-++-$ & 86 & 0.3 & 88 & 0.0 & 57 & $11 \cdot 0$ & 36 & $6 \cdot 8$ \\
\hline C. diversus I066-70 -+-+ & 84 & 0.6 & 84 & -- & 58 & $12 \cdot 7$ & 32 & - \\
\hline C. diversus $138 \mathrm{I}-70-+-+$ & 85 & 0.5 & 86 & - & 58 & $12 \cdot 9$ & 32 & $\ldots$ \\
\hline C. diversus $2292-70-+-+$ & 83 & $c \cdot 3$ & 84 & - & 57 & $13 \cdot 0$ & 33 & - \\
\hline C. diversus $3613-63-+-+$ & 84 & $c \cdot 3$ & 86 & - & 58 & $14 \cdot 2$ & 32 & - \\
\hline Bethesda IA +-++ & 51 & $12 \cdot 2$ & 26 & $8 \cdot 5$ & 54 & 14.0 & 25 & $8 \cdot 6$ \\
\hline Bethesda $3 \mathrm{~A}+-+-$ & 54 & $12 \cdot 0$ & 28 & $8 \cdot 9$ & 53 & $13 \cdot 7$ & 26 & $9 \cdot 1$ \\
\hline Bethesda $8 \mathrm{~A}+-++$ & 58 & $13 \cdot 8$ & 28 & $9 \cdot 5$ & 56 & $14 \cdot 2$ & 24 & $10 \cdot 0$ \\
\hline C. freundii $517-60$ ???? & 55 & $12 \cdot 9$ & 31 & $8 \cdot 9$ & 90 & 0.8 & 90 & 0.6 \\
\hline C. freundii $3796_{+}^{+}-+-+$ & 58 & $13 \cdot 4$ & 28 & $9 \cdot 4$ & 53 & 13.4 & 30 & $8 \cdot 8$ \\
\hline C. freundii $5118-60--+-$ & 52 & $12 \cdot 7$ & 29 & -1 & 52 & $14 \cdot 4$ & 26 & - \\
\hline C. freundii $876-58--++$ & 52 & $12 \cdot 9$ & $3 I$ & - & $5 \mathrm{I}$ & $13 \cdot 2$ & 26 & $\ldots$ \\
\hline C. freundii $460-61+-+-$ & 55 & $12 \cdot 6$ & 30 & -- & 55 & $14 \cdot 2$ & 28 & - \\
\hline C. freundii $4675-65+-+-$ & 54 & $13 \cdot 2$ & 33 & - & 55 & $13 \cdot 5$ & 27 & -- \\
\hline C. freundii $5245-60+-+-$ & 52 & $12 \cdot 5$ & $3 I$ & - & 53 & 13.0 & 26 & - \\
\hline
\end{tabular}

* See Table $\mathrm{I}$ for a definition of $\Delta T_{m(e)}$.

+ See Table $\mathrm{I}$ for plus and minus code.

$\ddagger$ These strains have atypical antigens.

size. Strain 1636-6I is highly related to two other +++- strains ( $1637-6 \mathrm{I}$ and $3104-61$ ), but exhibits only 54 to $55 \%$ relatedness with other citrobacteria. Strains 3 I $58-63$ and $80-58$ form highly stable duplexes. Since $87 \%$ of strain $3158-63$ is related to $7 \mathrm{I} \%$ of strain $80-$ 58 DNA, the $80-58$ genome is about $23 \%$ larger than that of $3158-63$. This genome size difference apparently explains the consistently higher relatedness of strain $3158-63$ to all citrobacteria tested, whereas the $\Delta T_{m(e)}$ values of heteroduplexes are similar whether the reference DNA is from strain 3I 58-63 or strain 80-58.

We next tested relatedness of L. malonatica and L. amalonatica to various groups of citrobacteria. Brenner, Fanning, Steigerwalt \& Young (1972) reported that these two Levinea species were 55 to $65 \%$ related, with I I to I $2 \%$ divergence in related sequences. Citrobacter diversus strains are -+-+ and $L$. malonatica strains are -+++ . The positive $\mathrm{KCN}$ reactions presented for L. malonatica are from the data of Young et al. (I97I). These were reported as delayed reactions. The data of Ewing \& Davis (1972) indicate that $C$. diversus (as well as strains of L. malonatica from Young's Laboratory) are KCN negative after $48 \mathrm{~h}$. These bacteria, therefore, may well be identical in this respect and we thank Dr Ewing for bringing this information to our attention. Citrobacter diversus and L. malonatica are extremely closely related (Table 4). Levinea amalonatica is closely related to the atypical C. freundii strain 5I7-60. DNA from 517-60 was prepared some years ago. Lyophiles of this strain were not viable when the present study was initiated, therefore this culture was not available for biochemical characterization. Both Levinea species exhibit approximately $55 \%$ relatedness to other groups of biochemically atypical citrobacteria and to typical C. freundii. The amount of divergence in these reactions is 12 to $14 \%$. In $75^{\circ} \mathrm{C}$ reactions, relatedness falls approximately twofold with a concomitant increase in heteroduplex thermal stability. 
Table 5. Relative relatedness of enterobacteria to lysine positive

'Citrobacter-like' strain 4556-7I

Source of unlabelled DNA

'Citrobacter-like' 4556-71 - - + + lys ${ }^{+}$

'Citrobacter-like' 4552-71 - - + lys ${ }^{+}$

'Citrobacter-like' 4553-7 I - - + + lys ${ }^{+}$

'Citrobacter-like' 4554-7I - + + lys'

'Citrobacter-like' 4557-7I - - + lys ${ }^{+}$

C. freundii $5245-60+-+-$

C. freundii $460-61+-+-$

C. freundii 3062-62 +-+-

C. freundii 4675-65 +-+-

Bethesda $3 \mathrm{~A}+-+-$

C. freundii $876-58--++$

C. freundii $6440-59--++$

C. freundii $2987-57--+-$

C. freundii 5118-60-- +-

Bethesda $6+-++$

Bethesda 29A +-++

C. diversus 1066-70 - + - +

$C$. diversus 1381-70 -+-+

C. diversus 2292-70 -+-+

C. diversus 3613-63 -+-+

L. malonatica $25408-+++$

L. malonatica $25409-+++$

L. malonatica $25410-+++$

L. amalonatica $25405-++-$

L. amalonatica $25407-++-$

E. coli KI2

S. typhimurium LT2

$K$. pneumoniae 2

E. aerogenes $1627-66$

E. cloacae $\mathrm{I} 347-7 \mathrm{I}$

E. agglomerans $\mathrm{EH} 103$

E. hafniae

Edwardsiella tarda 1795-62

$P$. carotovorum 495

E. amylovora EA 178

S. marcescens SM6-W2

\begin{tabular}{|c|c|}
\hline $\begin{array}{c}\text { Binding } \\
\text { at } 60 \mathrm{C} \\
(\%)\end{array}$ & $\begin{array}{l}\Delta T_{m+e)}{ }^{*} \\
\text { at } 60{ }^{\circ} \mathrm{C}\end{array}$ \\
\hline 100 & - \\
\hline 96 & 0.8 \\
\hline 94 & I. 3 \\
\hline 93 & $1 \cdot 2$ \\
\hline 94 & $\mathrm{I} \cdot 5$ \\
\hline 28 & $17 \cdot 3$ \\
\hline 25 & 16.6 \\
\hline 28 & $17 \cdot 7$ \\
\hline 30 & $17 \cdot 7$ \\
\hline 28 & $15 \cdot \mathrm{I}$ \\
\hline 27 & $\mathrm{I} 8 \cdot \mathrm{I}$ \\
\hline 28 & $17 \cdot 6$ \\
\hline 25 & $18 \cdot 3$ \\
\hline 28 & 17.5 \\
\hline 27 & $16 \cdot 5$ \\
\hline 26 & 15.1 \\
\hline 30 & 17.6 \\
\hline 28 & 16.7 \\
\hline 28 & $17 \cdot I$ \\
\hline 28 & 17.0 \\
\hline 26 & 14.5 \\
\hline 28 & $14 \cdot 6$ \\
\hline 27 & $15 \cdot 1$ \\
\hline 27 & 16.9 \\
\hline 28 & 14.9 \\
\hline 25 & 14.7 \\
\hline 22 & 15.0 \\
\hline 31 & - \\
\hline 28 & \\
\hline 28 & - \\
\hline 25 & $\cdots$ \\
\hline 27 & - \\
\hline 23 & - \\
\hline 24 & \\
\hline 22 & $\ldots$ \\
\hline 47 & $\cdots$ \\
\hline
\end{tabular}

* See Table I for a definition of $\Delta T_{\text {m(e) }}$.

+ See Table $\mathrm{I}$ for plus and minus code.

Table 5 shows data obtained with reference DNA from a lysine ${ }^{+}$'Citrobacter-like' strain. The five lysine strains are extremely closely related. These strains are only distantly related to any group of Citrobacter strains. The only enterobacterium to which they exhibit greater than $30 \%$ relatedness is $S$. marcescens.

Reciprocal DNA reassociation reactions at $60{ }^{\circ} \mathrm{C}$ are shown in Table 6 . These data clearly demonstrate non-reciprocal levels of reassociation in almost all cases. The nonreciprocity reflects differences in the genome size of these organisms. For instance, the larger values obtained using labelled DNA from $C$. freundii 460-6 I indicate that this organism has a smaller genome than C. freundii 876-58, Levinea species or Salmonella typhimurium.

Relative genome sizes calculated from reciprocal reassociation data are shown in Table 7. Also shown in Table 7 are relative genome sizes obtained spectrophotometrically. 
Table 6. Reciprocal DNA reactions

\begin{tabular}{|c|c|c|}
\hline Source of labelled DNA & Source of unlabelled DNA & $\begin{array}{l}\text { Relative } \\
\text { reassociation } \\
\text { at } 60^{\circ} \mathrm{C}\end{array}$ \\
\hline C. freundii $460-6$ I & C. freundii $876-58$ & 80 \\
\hline C. freundii $876-58$ & C. freundii $460-6 \mathrm{I}$ & 69 \\
\hline C. freundii $460-6 \mathrm{I}$ & L. malonatica 25408 & 64 \\
\hline L. malonatica 25408 & C. freundii $460-6 \mathrm{I}$ & 55 \\
\hline C. freundii $460-6 \mathrm{r}$ & L. amalonatica 25406 & 66 \\
\hline L. amalonatica 26406 & C. freundii $460-6 \mathrm{I}$ & 55 \\
\hline C. freundii $460-6 \mathrm{r}$ & S. typhimurium LT2 & 60 \\
\hline S. typhimurium LT2* & C. freundii $460-6 \mathrm{I}$ & 50 \\
\hline C. freundii 3 I 58-63 & C. freundii $\mathrm{I} 636-6 \mathrm{I}$ & 55 \\
\hline C. freundii $\mathrm{I} 636-6 \mathrm{I}$ & C. freundii $3=58-63$ & 43 \\
\hline C. freundii $3158-63$ & C. freundii $80-58$ & 87 \\
\hline C. freundii $80-58$ & C. freundii $3158-63$ & $7 \mathrm{I}$ \\
\hline C. freundii $\mathrm{I} 636-6 \mathrm{I}$ & C. freundii $80-58$ & 48 \\
\hline C. freundii $80-58$ & C. freundii $\mathrm{I} 636-6 \mathrm{I}$ & 46 \\
\hline
\end{tabular}

* Data from Crosa, Brenner, Ewing \& Falkow (1973).

Each reaction is normalized to that of the respective homologous reassociation.

Table 7. Determination of genome size relative to that of $C$. freundii $460-6 \mathrm{I}$

$\begin{array}{cc}\text { Relative } & \text { Relative } \\ \text { genome } & \text { genome } \\ \text { size from } & \text { size from } \\ \text { spectro- } & \text { reciprocal } \\ \text { photometric } & \text { hybridization } \\ \text { determination } & \text { reactions }\end{array}$

\begin{tabular}{|c|c|}
\hline Organism & determination \\
\hline C. freundii $460-61$ & 100 \\
\hline freundii 5 I I 8-60 & 112 \\
\hline freundii $4675-65$ & 126 \\
\hline freundii $876-53$ & I I 4 \\
\hline Bethesda $8 \mathrm{~A}$ & 106 \\
\hline Bethesda 29A & I 13 \\
\hline C. diversus 1066-70 & I 23 \\
\hline malonatica 25408 & $\mathrm{I} 2 \mathrm{I}$ \\
\hline amalonatica 25406 & 一 \\
\hline typhimurium $\mathrm{LT} 2$ & 116 \\
\hline E. coli $\mathrm{K} 12$ & 108 \\
\hline
\end{tabular}

The estimation of the genome size spectrophotometrically was accomplished by a modification of the method of Gillis, De Ley \& De Cleene (1970). Sheared DNA at an absorbance at $260 \mathrm{~nm}$ of $2 \cdot 000 \pm 0 \cdot 010$ in $2 \times \mathrm{SSC}$ (SSC $=0.15 \mathrm{M}-\mathrm{NaCl}+0.015 \mathrm{M}$-sodium citrate) was denatured by heating in a boiling water bath for $5 \mathrm{~min}$. The DNA was then transferred to $10 \mathrm{~mm}$ curvettes in a $70^{\circ} \mathrm{C}$ chamber of a Gilford 2000 Spectrophotometer set at a $\Delta E$ of 0.25 in the vicinity of 2 . The absorbancy of each sample and the temperature were recorded automatically at 40 s intervals on a Minneapolis Honeywell recorder for $60 \mathrm{~min}$. The decrease in absorbancy during $30 \mathrm{~min}$, beginning $10 \mathrm{~min}$ after initiation of the renaturation process, was employed in the calculation of the molecular complexity of the DNA as described by Crosa et al. (I973). Each reaction was repeated five or more times.

Data obtained by these two methods are similar, and indicate that the extremes of genome size in citrobacteria vary by at least $25 \%$.

Citrobacteria form several relatedness groups. Typical C. freundii exhibit 40 to $60 \%$ relatedness to most other enterobacteria. These data are perhaps best demonstrated by plotting the distribution of relatedness of groups of organisms against a reference strain. Figure I shows relatedness at $60{ }^{\circ} \mathrm{C}$ of enterobacteria to $C$. freundii $460-6 \mathrm{I}$. The mode for typical strains of $C$. freundii, including most strains of Bethesda, is 9 I to $95 \%$. Biochemically 


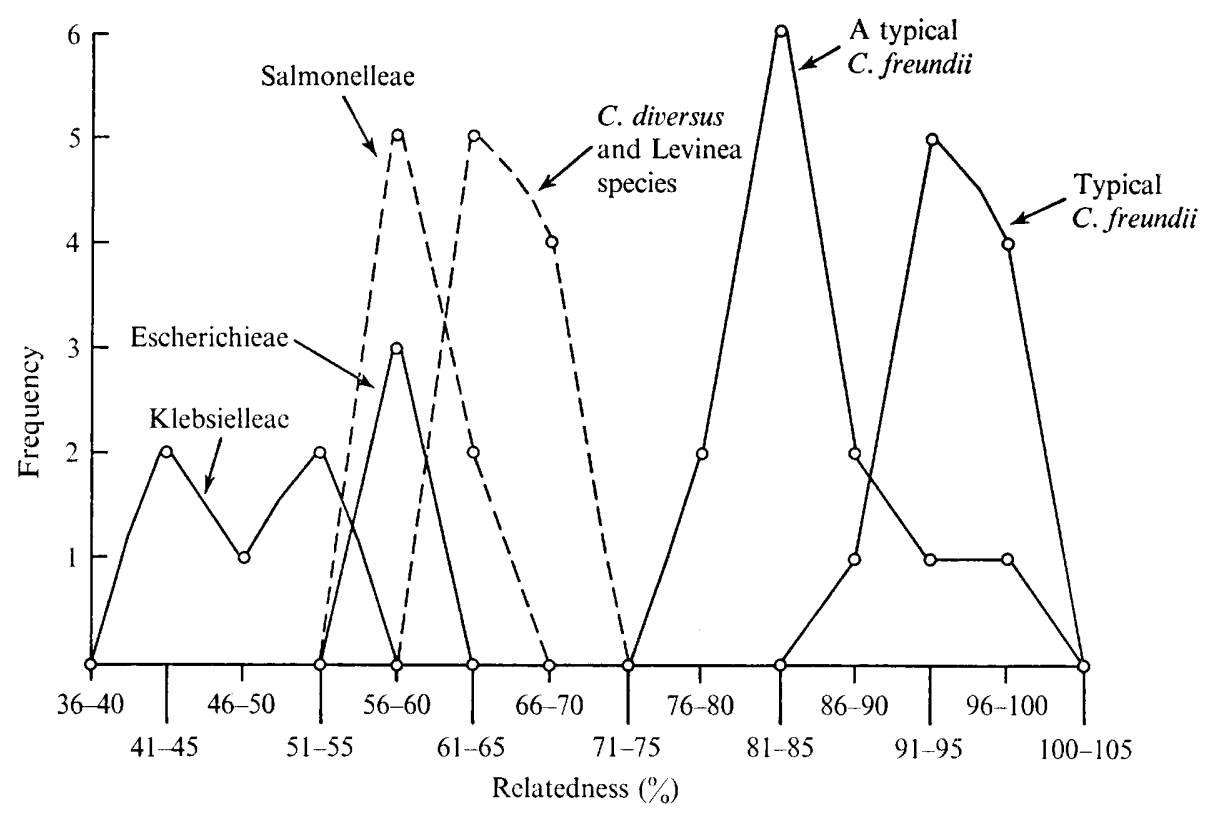

Fig. I. Distribution of relatedness of strains to Citrobacter freundii 460-61. Values shown were obtained from $60 \mathrm{C}$ reassociation reactions in which $C$. freundii 460-6I was the reference strain.

and antigenically atypical $C$. freundii strains are distributed around a mode of $8 \mathrm{I}$ to $85 \%$. There is some overlap between the atypical and typical strains. Relatedness of both $C$. diversus and Levinea species is distributed between $6 \mathrm{I}$ and $70 \%$. Relatedness of $C$. freundii to Salmonelleae is no higher than relatedness of $C$. freundii to Escherichieac.

\section{DISCUSSION}

Polynucleotide sequence relatedness studies at both optimal $\left(60^{\circ} \mathrm{C}\right)$ and stringent $\left(75^{\circ} \mathrm{C}\right)$ DNA reassociation criteria were carried out to determine the extent of divergence in bacteria biochemically and/or immunologically related to $C$. freundii. Although Citrobacter, Levinea and Bethesda (with the exception of the $\mathrm{H}_{2} \mathrm{~S}^{-}$, lysine ${ }^{+}$'Citrobacter-like' strains) all exhibit about $50 \%$ relatedness to Salmonelleae (Crosa et al. 1973), these bacteria are not a homogeneous group. The diversity exhibited among members of the genus Citrobacter is not surprising in view of their antigenic variability (Davis \& Ewing, 1966, 1971 ; Ewing \& Davis, 1972), and the differences in fatty acid composition (Machtiger \& O'Leary, 1973).

In agreement with the conclusions reached by several investigators (see Edwards \& Ewing, 1972), we find no reason to distinguish the Bethesda group from $C$. freundii solely on the basis of slow lactose fermentation.

Biochemically typical $(+-+-)$ C. freundii (and Bethesda) belong to one relatedness group. Two $\mathrm{H}_{2} \mathrm{~S}^{-}$strains, 5I $18-60(--+-)$ and 6440-59 $(--++)$ are included in this group. The level of relatedness among these organisms is approximately $95 \%$, with an average of less than $1.5 \%$ divergence within the related sequences. This relatedness group may be broadened to include most of the antigenically and biochemically atypical citrobacteria. Citrobacter freundii 460-6I exhibits an average of $80 \%$ relatedness to these strains.

The biochemically atypical strains exhibit considerable heterogeneity. Citrobacter freundii $876-58$, a --++ strain, shows similar relatedness to typical +-+- strains, to atypical 
,,--++--+--+++ (Table 2 ), and to +++- strains (Table 3 ). In all cases, the level of relatedness is 70 to $80 \%$, with 6 to $8 \%$ divergence. Further evidence for heterogeneity among biochemically atypical strains is found among +++- strains (Table 3 ). These bacteria can be divided into three groups based on reactions with +++- reference strains $3{ }^{1} 58-63$ and 80-58. Strains 31 58-63, 80-58, 2990-58, Bethesda 6 and Bethesda 29A are most highly related, based both on percentage relatedness and on heteroduplex stability. Relatedness of +++- strains 3104-61 and 3970-59 to +++- reference strains 3158-63 and $80-58$ is no higher than that of other atypical or typical strains. In general, relatedness is higher with strain $3158-63$ than with strain $80-58$. This is presumably due to the larger genome size of $80-58$.

The +++- strains $1636-61$ and $1637-61$ form a separate relatedness group. These strains are essentially identical and exhibit only some $50 \%$ relatedness to all other strains of $C$. freundii. Strain 3104-6I appears to be a link between these two strains and other C. freundii (Table 3 ).

Levinea malonatica $(-+++)$ and $C$. diversus $(-+-+)$ comprise one relatedness group. These organisms are 50 to $60 \%$ related to other citrobacteria. Levinea amalonatica strains $(-++-)$ are significantly different from $L$. malonatica, although utilization of malonate seems to be the only biochemical characteristic in which they differ (Young et al. 197I).

$\mathrm{H}_{2} \mathrm{~S}^{-}$, lysine ${ }^{+\cdot}$ 'Citrobacter-like' strains form a very closely related group. These bacteria are not closely related to any member of the genus Citrobacter. Of the bacteria tested they are most highly related to $S$. marcescens, although the level of relatedness is certainly less than that present among strains of $S$. marcescens.

As shown in Tables 5 and 6, genome sizes in the genus Citrobacter can vary by at least as much as $25 \%$. Therefore it is possible that the heterogeneity observed among strains of $C$. freundii is the result of genome size differences. For example, suppose that $C$. freundii strains $\mathrm{A}$ and $\mathrm{B}$ contain identical sequences of $2 \times 10^{9}$ daltons, and that the genome in strain $\mathrm{A}$ is $2 \times 10^{9}$ daltons compared with $3 \times 10^{9}$ daltons in strain B. Labelled DNA from strain A will exhibit $100 \%$ relatedness to DNA from strain B; however, labelled DNA from strain $B$ will exhibit only $67 \%$ relatedness to DNA from strain $A$. In this case the thermal stability of $A / B$ and $B / A$ reactions will be identical and identical to the thermal stability of $\mathrm{A} / \mathrm{A}$ and $\mathrm{B} / \mathrm{B}$ reactions. In the Citrobacter reactions reported here, a lower level of relatedness is accompanied by a decrease in thermal stability. We therefore feel certain that the heterogeneity observed among atypical strains of $C$. freundii (except where specifically correlated with genome size differences) is not simply the result of differences in genome size.

Differences in $\mathrm{H}_{2} \mathrm{~S}$, indole, $\mathrm{KCN}$ and malonate reactions were used by Ewing (Davis \& Ewing, 1966, 1971; Ewing \& Davis, 1972; Edwards \& Ewing, 1972) as the basis for differentiating between $C$. diversus and $C$. freundii and for the formation of biogroups in C. freundii. In some hybridization groups there is a good correlation between DNA relatedness and the biochemical reactions for $\mathrm{H}_{2} \mathrm{~S}$, indole, $\mathrm{KCN}$ and malonate. In atypical $C$. freundii, differences in these biochemical reactions cannot account for the large differences in relatedness, nor can they account for the relatedness differences present between $C$. diversus and $C$. freundii. Other than malonate utilization there is at present no biochemical basis for distinguishing L. malonatica from L. amalonatica. Both Ewing (Davis \& Ewing, 1966, 1971; Ewing \& Davis, 1972; Edwards \& Ewing, 1972) and Bascomb, Lapage, Curtis \& Willcox (1973) have examined a great many additional biochemical characters in Citrobacter. They found some 6 to 8 additional biochemical differences 
between $C$. freundii and $C$. diversus (and Levinea species), but these differences are not present in all strains of one group and absent in all strains of the other group. Furthermore, the inclusion of these differences cannot account for more than a small portion of the relatedness differences.

Bascomb et al. (1973) were successful in identifying $93 \%$ of 6I C. freundii biotype 1 strains and $95 \%$ of $20 \mathrm{C}$. freundii biotype 2 strains using a numerical taxonomy program. They arbitrarily placed all $C$. freundii strains in biotype I and all Levinea (including $C$. diversus), Padlewskia and $C$. koseri strains in biotype 2 . The amount of heterogeneity present between strains of both biotypes is emphasized by the presence of 20 different biopatterns in the 20 biotype 2 strains and 43 biopatterns in the 6 I biotype I strains examined by Bascomb et al. (1973).

Another approach that is potentially useful in determining the extent of divergence among citrobacteria is that of gene transfer and recombination (de Graff \& Stouthamer, 197I; 1972; de Graaff, Barendsen \& Stouthamer, 1973; de Graaff, Kreuning \& van de Putte, 1973; de Graaff, Kreuning \& Stouthamer, 1974). The rationale for these studies is that the efficiency of gene transfer and recombination is highest between closely related strains and falls off rapidly as relatedness between strains decreases.

With respect to speciation in the genus Citrobacter, we feel the following scheme is appropriate (for the +-+- code, see p. 272): (i) $C$. freundii is comprised of typical +-+- strains, as well as atypical strains of biotype,--+---++ , and +++(unless otherwise specified). (ii) The +++- strains I636-6I and I637-6I require further study both biochemically and by hybridization, before a decision is made as to whether they should be placed in a species separate from $C$. freundii. (iii) The -+-+ strains (C. diversus and L. malonatica) belong to one species separate from C. freundii. Citrobacter diversus is the prior designation; therefore this species should include L. malonatica strains. (iv) The -++- strains belong to a species distinct from $C$. freundii and $C$. diversus. Levinea amalonatica is a properly published name with priority. It seems, however, that this species should also be included in Citrobacter.

$\mathrm{H}_{2} \mathrm{~S}^{-}$, lysine ${ }^{+}$strains are not members of the genus Citrobacter. They show relatedness indicative of the genus level to $S$. marcescens. Further study is necessary before these organisms are speciated.

We thank G. Hermann and W. H. Ewing who generously provided most of the cultures used in this study. We are extremely indebted to W. H. Ewing and S. Falkow for their candid comments and continued interest and encouragement in our work. J. H. Crosa is a Fellow of the World Health Organization and is on leave of absence from Centro de Investigaciones, Microbiologicas, Facultad de Ciencias Exactas, University of Buenos Aires, Argentina.

\section{REFERENCES}

Bascomb, S., Lapage, S. P., Curtis, M. A. \& Willcox, W. R. (1973). Identification of bacteria by computer: identification of reference strains. Journal of General Microbiology 77, 291-315.

Brenner, D. J., Fanning, G. R., Johnson, K. E., Citarella, R. V. \& Falkow, S. (1969a). Polynucleotide sequence relationships among members of the Enterobacteriaceae. Journal of Bacteriology 98, 637-650.

Brenner, D. J., Fanning, G. R., Rake, A. \& Johnson, K. E. (1969b). A batch procedure for the thermal elution of DNA from hydroxyapatite. Analytical Biochemistry 28, 447-459.

Brenner, D. J., Fanning, K. E., Steigerwalt, A. G. \& Young, V. M. (1972). DNA relatedness among Levinea species and enterobacteria. Bacteriological Proceedings 12, 58.

Britten, R. J. \& KohNe, D. E. (1966). Nucleotide sequence repetition in DNA. Carnegie Institution of Washington Year Book 65, 78-106. 
Crosa, J. H., Brenner, D. J., Ewing, W. H. \& Falkow, S. (1973). Molecular relationships among the Salmonelleae. Journal of Bacteriology $115,307-315$.

Davis, B. R. \& EwING, W. H. (1966). The Biochemical Reactions of Citrobacter freundii. Atlanta, Georgia: U.S. National Communicable Disease Center.

Davis, B. R. \& EwING, W. H. (197I). Biochenical Characterization of Citrobacter freundii and Citrobacter diversus. Atlanta, Georgia: Center for Disease Control.

Edwards, P. R. \& EwING, W. H. (1972). Identification of Enterobacteriaceae, 3rd edn. Minneapolis, Minnesota, U.S.A.: Burgess Publishing.

EwING, W. H. \& DAvis, B. R. (1972). Biochemical characterization of Citrobacter diversus (Burkey) Werkman \& Gillen and designation of the neotype strain. International Journal of Systematic Bacteriology 22, I 2-I8.

FredRICKSEN, W. (1970). Citrobacter koseri (n. sp.). A new species within the genus Citrobacter, with a comment on the taxonomic position of Citrobacter intermedium (Werkman \& Gillen). Publication de la Faculte des Sciences de l'Universite J. E. F'urkyne, Brno 47, 89-94.

Gillis, M., De Ley, J. \& De Cleene, M. (1970). The determination of molecular weight of bacterial genome DNA from renaturation rates. European Journal of Biochemistry 12, $143^{-1} 53$.

de GraAfF, J., Barendsen, W. \& Stouthamer, A. H. (I973). Mapping of chlorate-resistant mutants of Citrobacter freundii by deletion and complementation analysis. Molecular and General Genetics r2r, 259-269.

de Graff, J., Kreuning, P. C. \& van de Putte, P. (1973). Host controlled restriction and modification of bacteriophage $\mathrm{Mu}$ and $\mathrm{Mu}$-promoted chromosome mobilization in Citrobacter freundii. Molecular and General Genetics 123, 283-288.

de Graff, J., Kreuning, P. C. \& Stouthamer, A. H. (1974). Isolation and characterization of Hfr males in Citrobacter freundii. Antonie van Leeuwenhoek. Journal of Microbiology and Serology 40 (in the Press).

DE Graff, J. \& Stouthamer, A. H. (I97I). Citrobacter freundii mutants deficient in host specificity functions and their recipient ability for foreign deoxyribonucleic acid. Journal of General Microbiology 67, 9I-97.

De Graff, J. \& Stouthamer, A. H. (1972). Properties of a temperature sensitive plasmid in Citrobacter freundii. Molecular and General Genetics I19, 259-266.

Laird, C. D., McConaughy, B. L. \& MCCar rhy, B. J. (I969). On the rate of fixation of nucleotide substitutions in evolution. Nature, London 22.4, I49-154.

Leclerc, H. \& Buttiaux, R. (1965). Les Citrobacter. Annales de l'Institute Pasteur 16, 67-74.

Machtiger, N. A. \& O'Leary, W. M. (1973). Fatty acid compositions of paracolons: Arizona, Citrobacter and Providencia. Journal of Bacteriology 114, 80-85.

MACierwitz, M. (1966). A new proposal of a new group (genus) of Enterobacteriaceae. Medycyna Doswiadczalna i Mikrobiologia $\mathbf{1 8}, 333-339$.

Young, V. M., Kenton, D. M., Hobbs, B. J. \&: Moody, M. R. (I97I). Levinea, a new genus of the family Enterobacteriaceae. International Journal of Systematic Bacteriology 21, 58-63. 